\title{
Peran Kecerdasan Emosi dan Iklim Organisasi terhadap Perilaku Kerja Kontraproduktif
}

\author{
Devianita Puspita Wardhani ${ }^{1}$ E IJK Sito Meiyanto ${ }^{2}$ \\ Fakultas Psikologi Universitas Gadjah Mada
}

\begin{abstract}
This research aims to determine the role of emotional intelligence and organizational climate in predicting the counterproductive work behavior. This study used a quantitative approach survey. The method of data collection in this research was conducted by distributing scale to the research subjects, with a total of 146 civil servants. The data was analyzed using double regression techniques using SPSS (Statistical Product and Service Solutions) 20.0. The result shows that the emotional intelligence and organizational climate can contribute together to decrease counterproductive behavior that occurs in the workplace $\left(F(2,143)=5.266, p<.05, R^{2}=.069\right)$. Limitations and suggestions for further research were also discussed in this study.
\end{abstract}

Keywords: counterproductive work behavior; emotional intelligence; organizational climate

Abstrak. Penelitian ini bertujuan untuk menguji peran kecerdasan emosi dan iklim organisasi dalam memprediksi perilaku kerja kontraproduktif. Penelitian ini menggunakan pendekatan kuantitatif survei. Metode pengumpulan data pada penelitian ini dilakukan dengan menyebarkan skala kepada subjek penelitian, dengan jumlah 146 Pegawai Negeri Sipil (PNS). Data dianalisis dengan teknik regresi berganda menggunakan bantuan program SPSS (Statistical Product and Service Solutions) 20.0. Hasil penelitian menunjukkan bahwa kecerdasan emosi dan iklim organisasi dapat berperan secara bersama-sama untuk menurunkan perilaku kerja kontraproduktif yang terjadi di tempat kerja $\left(F(2,143)=5,266, p<0,05, R^{2}=0,069\right)$. Keterbatasan dan saran bagi penelitian selanjutnya turut didiskusikan dalam penelitian ini.

Kata kunci: iklim organisasi; kecerdasan emosi; perilaku kerja kontraproduktif;

Indonesia dan dunia telah berubah seiring berjalannya waktu, terutama ketika memasuki abad 21. Sejalan dengan perubahan dalam sistem pemerintahan, sektor perekonomian di Indonesia juga turut berubah (Ananta, Soekarni, \& Arifin, 2011). Hal ini ditandai pula dengan peningkatan karyawan yang terjadi setiap tahunnya, jumlah total karyawan menurut

\footnotetext{
1 Korespondensi mengenai isi artikel ini dapat dilakukan melalui: devianita.puspita.w@mail.ugm.ac.id

2 Atau melalui smeiyanto@ugm.ac.id
}

International Labour Organization (2016) adalah sebanyak 239.732 orang. Besarnya jumlah karyawan memicu peningkatan produktivitas yang ditandai dengan jumlah Gross Domestic Product (GDP). Indonesia pada tahun 2015 memiliki GDP sebesar 4328,9 US \$ per tahun pada masing-masing karyawan, sedangkan Malaysia 16408,9 US \$, hal ini menunjukkan produktivitas karyawan Indonesia masih jauh jika dibandingkan dengan Malaysia. 
Produktivitas organisasi tentunya juga dipengaruhi oleh perilaku kerja karyawannya. Dewasa ini penelitian terkait dengan perilaku kerja karyawan telah banyak diteliti, tidak hanya yang bersifat positif, namun perilaku negatif yang dapat merugikan organisasi juga mendapat perhatian khusus. Berbagai teori dan hasil penelitian telah memberikan penjelasan mengenai perilaku kerja kontraproduktif. Perilaku kerja kontraproduktif dapat diartikan sebagai seperangkat perilaku negatif yang merusak organisasi dengan mengganggu kegiatan operasional dan aset, atau dengan menyakiti rekan kerjanya sedemikian rupa sehingga dapat menurunkan efisiensi dari karyawan tersebut (Bashir, Nasir, Qayyum, \& Bashir, 2012; Fox, Spector, dan Miles, 2001; Spector \& Fox, 2005). Contoh dari perilaku kerja kontraproduktif adalah sebagai berikut: keterlambatan waktu kerja, pencurian, penyabotan, dan perbuatan jahat dalam bentuk verbal atau fisik di tempat kerja. Perilaku kerja kontraproduktif dilakukan atas dasar kesengajaan, di mana seseorang memiliki niat untuk melakukan tindakan tersebut.

Survei yang dilakukan oleh Pricewaterhouse Coopers (2016) menunjukkan bahwa $36 \%$ organisasi di seluruh dunia mengalami kecurangan sebagai bentuk kejahatan ekonomi dalam 24 bulan terakhir, yang berdampak sangat besar bagi produktivitas organisasi. Mazolla dan Kessler (2012) menyimpulkan bahwa perilaku kerja kontraproduktif merupakan perilaku yang umum terjadi di lingkungan kerja dan menyebabkan kerugian finansial baik bagi organisasi maupun anggotanya. Studi menujukkan pencurian dan kecurangan oleh karyawan adalah bentuk kriminalitas yang tumbuh paling cepat di Amerika Serikat (Coffin dalam Ellias, 2013). Sebanyak 75\% karyawan melakukan pencurian dari atasannya dan 95\% dari organisasi mengalami pencurian aset yang dilakukan oleh karyawan. Coffin dalam Ellias (2013) juga menyatakan bahwa kerugian yang disebabkan pencurian oleh karyawan mencapai 50 milyar USD setiap tahunnya. Apabila hal tersebut tidak dikontrol organisasi tentu akan mengalami kerugian yang signifikan secara finansial (Ahmad \& Norhashim, 2008).

Aquino, Galperin, dan Bennett (2004) menyatakan bahwa perilaku kerja kontraproduktif kerapkali terjadi di sektor publik dibandingkan dengan sektor swasta. Hal ini juga terjadi di Indonesia di mana data menunjukkan bahwa Pegawai Aparatur Sipil Negara (ASN), yang di dalamnya terdiri dari Pegawai Negeri Sipil (PNS) sebagai karyawan di sektor publik terbukti melakukan pelanggaran. Dilansir oleh situs berita online Prokal.co (2016) menunjukkan bahwa selama dua tahun terakhir sebanyak 45 pegawai terbukti melanggar peraturan disiplin berat dengan mendapatkan sanksi pemecatan.

Penelitian yang berkaitan dengan perilaku kerja kontraproduktif, dilakukan untuk melihat faktor-faktor yang dapat menuntun seseorang pada perilaku ini (Bowling \& Eschleman, 2010; Spector \& Fox, 2005). Hal ini didasari fakta bahwa dalam beberapa tahun belakangan karyawan telah terbukti memiliki keterlibatan dengan perilaku yang dapat merugikan organisasi. Saat ini apa yang karyawan lakukan dan katakan di tempat kerja, diklasifikasikan ke dalam orangorang yang bermanfaat atau justru karyawan yang menimbulkan kerugian bagi organisasi (Klotz \& Buckley, 2013; Spector \& Fox, 2002). Martinko, Gundlach, dan Douglas (2002) sejalan dengan Fox, et al. (2001) menjelaskan bahwa penyebab perilaku kerja kontraproduktif umumnya 
dikelompokkan menjadi dua faktor, yaitu situasional dan individual.

Beberapa penelitian di atas menunjukkan adanya faktor perbedaan individu dan faktor situasional sebagai variabel yang dapat menyebabkan munculnya perilaku negatif di tempat kerja yang disebut perilaku kerja kontraproduktif. Salah satu variabel yang dapat menjadi faktor yang menurunkan perilaku kerja kontraproduktif di tempat kerja adalah kecerdasan emosional. Hal ini dikarenakan karyawan dengan kecerdasan emosi yang baik akan cenderung menghindari perilaku kerja kontraproduktif (Emami, 2014; Yin, 2010). Sejalan dengan penelitian tersebut Jung dan Yoon (2012), Ying dan Ting (2013) juga membuktikan bahwa terdapat korelasi negatif antara kecerdasan emosi yang dimiliki seseorang terhadap perilaku kerja kontraproduktif dalam bekerja.

Davies, Stankov, dan Roberts (1998) sejalan dengan Mayer dan Salovey (1997) mengartikan kecerdasan emosi sebagai hal yang dilakukan seseorang mengenai cara mengelola emosinya. Hal ini menjadi gambaran bahwa individu yang mampu mengelola emosinya dapat menentukan sikap yang tepat sebelum bertindak, sehingga tidak merugikan organiasi. Van Rooy dan Viswesvaran (2004) mengungkapkan bahwa karyawan dengan kecerdasan emosi yang tinggi cenderung untuk menunjukkan performa kerja yang baik dan bertindak sesuai dengan kode etik yang ada di organisasi. Selanjutnya kecerdasan emosi yang rendah juga terbukti membuat karyawan berperilaku negatif di tempat kerja, bahkan tidak segan untuk melanggar aturan yang ada di organisasi tersebut (Deshpande, Joseph, \& Shu, 2005; Petrides, Fredrickson, \& Furnham, 2004).

Selain faktor internal berupa perbedaan dalam diri individu, sisi lain yang dapat menjadi bahan penelitian terkait perilaku kerja kontraproduktif adalah melihat faktor situasional sebagai prediktor atas perilaku kerja kontraproduktif. Iklim organisasi, sebagai salah satu faktor yang terbukti menjadi hal yang dapat memengaruhi perilaku kerja kontraproduktif menjadi hal yang menarik untuk dibahas. Perusahaan sebagai sebuah tempat bagi karyawan untuk mengembangkan potensinya yang dapat berdampak bagi produktivitas organisasi perlu memiliki iklim organisasi yang baik. Chernyak-Hai dan Tziner (2013), bahwa perusahaan yang memiliki iklim organisasi positif dilaporkan memiliki perilaku kerja kontraproduktif yang semakin rendah. Kanten dan Ülker (2013) yang melakukan penelitian mengenai iklim organisasi, melihat masing-masing aspek iklim organisasi memiliki pengaruh terhadap perilaku kerja kontraproduktif.

Mengacu pada kajian teoritis dan empiris yang telah dijelaskan, diperoleh gambaran umum mengenai keterkaitan variabel yang akan diteliti. Menurut Sonnentag dan Frese (2002), organisasi perlu meningkatkan performa individu untuk mencapai tujuan perusahaan, agar penjualan produk semakin meningkat dan mencapai keunggulan kompetitif. Keunggulan kompetitif inilah yang kemudian dapat menjadi modal bagi perusahaan untuk mampu bersaing di dunia bisnis. Sumber daya manusia sebagai aset organisasi yang melakukan perilaku kerja kontraproduktif, perlu mendapat perhatian khusus untuk mengetahui kondisi yang memicu terjadinya perilaku ini.

Besarnya kerugian dan bahayanya dampak sosial maupun psikologis yang disebabkan oleh perilaku kerja negatif tersebut, menyebabkan penelitian yang memberikan penekanan pada perilaku kerja kontraproduktif tetap dirasa penting. 
Studi empiris yang dilakukan Penney dan Spector (2005) juga menunjukkan bahwa penelitian mengenai perilaku kontraproduktif akan menjadi topik yang sangat menarik bagi organisasi dan para peneliti karena terkait dengan besarnya biaya yang disebabkan oleh perilaku ini. Dewasa ini perilaku kerja karyawan dipandang sebagai bentuk upaya pengembangan sumber daya manusia Indonesia untuk meningkatkan kualitas tenaga kerja dan peran sertanya dalam meningkatkan produktivitas (Republik Indonesia, 2003).

Peneliti akan melakukan penelitian mengenai hubungan antara kecerdasan emosi, iklim organisasi, dan perilaku kerja kontraproduktif untuk melihat kondisi tersebut di Indonesia. Studi literatur yang dilakukan oleh peneliti, menunjukkan belum banyak penelitian mengenai hubungan ketiga variabel ini di Indonesia. Selanjutnya peneliti mempertimbangkan untuk melakukan penelitian pada PNS di Dinas Pekerjaan Umum daerah Kalimantan Timur dan Kalimantan Utara.

\section{Metode}

Penelitian ini menggunakan desain penelitian kuantitatif. Pendekatan kuantitatif dilakukan dengan metode survei, yaitu pengisian skala oleh subjek penelitian. Subjek pada penelitian ini adalah karyawan tetap yang bekerja di perusahaan publik (PNS), serta bekerja di kantor. Karakteristik dari subjek penelitian, sebagai berikut: (1) karyawan tetap di perusahaan tempat pengambilan data, (2) telah bekerja selama minimal enam bulan. Pengambilan data dilakukan di Dinas Pekerjaan Umum (PU), di mana memenuhi syarat PNS dan terdapat karyawan teknikal maupun manajerial. Metode pemilihan sampel menggunakan cara single stage, di mana peneliti telah menentukan organisasi yang sesuai dengan karakteristik penelitian (Creswell, 2012). Teknik pengambilan sampel yang akan digunakan dalam penelitian ini adalah teknik convenience sample yaitu pemilihan sekelompok subjek didasarkan pada kemudahan dan ketersediaan data pada subjek di dalam organisasi yang ditentukan (Creswell, 2012).

Proses pengukuran dilakukan dengan menggunakan tiga skala alat ukur untuk menguji tiga variabel. Alat ukur yang akan digunakan, telah melalui proses adaptasi yang akan mengikuti tahapan dari Beaton, Bombardier, Guillemin, dan Ferraz (2000). Awalnya alat ukur yang berbahasa Inggris akan diterjemahkan ke bahasa Indonesia menggunakan native translator. Selanjutnya, translasi juga dilakukan oleh informed translator yang merupakan rekan mahasiswa Profesi Psikologi Industri dan Organisasi, yang sudah tidak asing dengan konstrukkonstruk dalam penelitian psikologi. Tahap terakhir adalah melakukan backtranslation yang dilakukan dengan meminta bantuan orang berkebangsaan asing yang pernah tinggal di Indonesia dan memahami bahasa Indonesia.

Skala untuk mengukur perilaku kerja kontraproduktif disusun dan dikembangkan oleh Fox, Spector, dan Miles, (2001), dengan nama Counterproductive Work Behavior Checklist (CWB-C). Peneliti menggunakan versi skala pendek yang pertama kali digunakan oleh Spector, Bauer, dan Fox (2010) yang terdiri dari 10 aitem dengan nama Counterproductive Work Behavior Checklist (CWB-C). Alat ukur ini memiliki lima pilihan jawaban, di mana subjek penelitian akan diminta untuk memilih jawaban tidak pernah, pernah sesekali, 1-2 kali per bulan, 1-2 kali per minggu, dan selalu.

Kecerdasan emosi diukur dengan menggunakan skala Wong dan Law EI 
Scale (WLEIS) yang disusun berdasarkan teori Mayer dan Salovey (1997). Skala dengan 16 aitem yang pada masingmasing dimensi terdiri dari empat aitem dipilih diberikan kepada subjek dengan menggunakan skala likert lima pilihan jawaban. Pengukuran terhadap iklim organisasi dilakukan dengan menggunakan skala pendek dari PeñaSuárez, Muñiz, Campillo-Álvarez, Fonseca-Pedrero, dan García-Cueto (2013). Skala yang menjadi instrumen penelitian ini disusun dengan 15 aitem. Pilihan jawaban pada skala likert yang ada di dalam kuisioner bergerak dari STS (Sangat Tidak Sesuai), TS (Tidak Sesuai), N (Netral), S (Sesuai), dan SS (Sangat Sesuai). Pengujian hipotesis pada penelitian ini akan dilakukan dengan teknik analisis regresi berganda menggunakan program SPSS (Statistical Product and Service Solutions) 20.0 .

\section{Hasil}

Proses uji coba dilakukan dengan menyebarkan kuisioner secara langsung kepada subjek coba yang mirip dengan karakteristik penelitian. Peneliti melibatkan 100 PNS di Dinas Pekerjaan Umum daerah Kalimantan Timur dan Kalimantan Utara, namun yang dapat dianalisis hanya 99 kuesioner. Tabel 1 menunjukkan bahwa keseluruhan skala yang digunakan telah lolos uji reliabilitas dan validitas, sehingga dapat digunakan untuk melakukan penelitian lebih lanjut guna mengumpulkan informasi yang digunakan.
Penelitian dilaksanakan di salah satu organisasi publik yang bergerak di bidang Pekerjaan Umum (PU) yang berlokasi di Kalimantan Timur. Pengambilan data dilakukan dengan menyebarkan kuisioner tertulis yang diisi oleh karyawan secara langsung. Kuisioner yang disebarkan sebanyak 180 buah, namun yang kembali sebanyak 160 dan setelah melakukan pengecekan awal, kuisioner yang dirasa memenuhi syarat oleh peneliti adalah sebanyak 146 .

Tabel 2 menunjukkan bahwa 64,38\% responden penelitian adalah laki-laki dan $35,62 \%$ responden penelitian adalah wanita. Persentase tersebut menunjukkan bahwa karyawan dinas PU Kalimantan Timur lebih banyak yang berjenis kelamin laki-laki. Hal ini sesuai dengan jenis pekerjaan yang berkaitan dengan pembangunan suatu daerah dan latar belakang pendidikan yang kebanyakan bersifat teknikal. Selanjutnya tabel 2 juga dapat menunjukkan bahwa latar belakang pendidikan didominasi oleh Strata satu dengan jumlah 58,21\%.

Hasil pengelompokan responden pada tabel 2 menunjukkan data persebaran usia responden. Persentase karyawan yang berusia 20-30 tahun merupakan jumlah terbanyak sebesar $35,62 \%$, usia 31-40 tahun sebesar 30,14\%, usia 41-50 tahun 23,97\%, dan persentase paling kecil adalah karyawan yang berusia di atas 50 tahun dengan jumlah 6,85\%. Data tersebut menunjukkan bahwa karyawan dinas PU Kalimantan Timur masih banyak yang berada pada usia

Tabel 1.

Hasil Uji Coba Alat Ukur

\begin{tabular}{lcccccc}
\hline \multicolumn{1}{c}{ Variabel } & $\begin{array}{c}\text { Jumlah } \\
\text { item }\end{array}$ & $\begin{array}{c}\text { Jumlah } \\
\text { item } \\
\text { gugur }\end{array}$ & KMO & Barlett & $\begin{array}{c}\text { Faktor } \\
\text { loading }\end{array}$ & $\begin{array}{c}\text { Cronbah } \\
\text { alpha }\end{array}$ \\
\hline $\begin{array}{l}\text { Perilaku Kerja } \\
\text { Kontraproduktif }\end{array}$ & 10 & 1 & 0,907 & $P<0,01$ & $0,470-$ & 0,942 \\
\hline $\begin{array}{l}\text { Kecerdasan } \\
\text { Emosi }\end{array}$ & 16 & 0 & 0,705 & $\mathrm{P}<0,01$ & $\begin{array}{c}0,461- \\
0,879\end{array}$ & 0,819 \\
\hline \multicolumn{1}{c}{ Iklim } & 15 & 0 & 0,839 & $\mathrm{P}<0,01$ & $0,444-$ & 0,879 \\
\multicolumn{1}{c}{ Organisasi } & & & & & 0,693 & \\
\hline
\end{tabular}


Tabel 2.

Komposisi Demografi Subjek

\begin{tabular}{|c|c|c|c|}
\hline $\begin{array}{c}\text { Jenis } \\
\text { Kelamin }\end{array}$ & Jumlah & $\begin{array}{c}\text { Tingkat } \\
\text { Pendidikan } \\
\end{array}$ & Jumlah \\
\hline Laki-laki & 94 & SMA/Sederajat & 37 \\
\hline Perempuan & 52 & D3 & 4 \\
\hline- & - & S1/Sederajat & 85 \\
\hline- & - & S2 & 11 \\
\hline \multirow[t]{2}{*}{ Missing } & 0 & Missing & 9 \\
\hline & 146 & & 146 \\
\hline Usia & Jumlah & Lama Kerja & Jumlah \\
\hline 20-30 tahun & 52 & 1-5 tahun & 47 \\
\hline 31-40 tahun & 44 & 6-10 tahun & 26 \\
\hline 41-50 tahun & 35 & 11-15 tahun & 30 \\
\hline$>50$ tahun & 10 & $>15$ tahun & 36 \\
\hline \multirow[t]{2}{*}{ Missing } & 5 & Missing & 7 \\
\hline & 146 & & 146 \\
\hline
\end{tabular}

muda. Persentase usia karyawan yang banyak berada pada rentang 20-30 tahun berpengaruh pula pada masa kerja karyawan yang juga banyak berada pada rentang 1-5 tahun dengan jumlah 32,19\%. Selanjutnya masa kerja karyawan dengan lama 6-10 tahun sebesar 17,81\%, karyawan dengan masa kerja 11-15 tahun sebesar $20,55 \%$, dan karyawan yang bekerja lebih dari 15 tahun sebesar 24,66\%.

Uji asumsi yang dilakukan yaitu uji linieritas, tujuannya adalah untuk melihat apakah spesifikasi model yang digunakan sudah benar atau tidak (Ghozali, 2013). Hasil uji lineritas menunjukkan semua variabel bebas dengan variabel terikat linier, sehingga dapat dikatakan memenuhi asumsi linieritas. Nilai linieritas pada variabel kriterium dan prediktor dalam penelitian ini lebih besar dari 0,05 (0,812 dan 0,179). Berdasarkan hasil uji asumsi klasik dengan melihat linieritas, maka data penelitian dapat dianalisis lebih lajut.

\section{Uji hipotesis}

Uji hipotesis mayor dilakukan untuk menguji peran kecerdasan emosi dan iklim organisasi secara bersama-sama terhadap perilaku kerja kotraproduktif, yaitu dengan menggunakan analisis regresi berganda. Hasil analisis regresi berganda menunjukkan nilai signifikansi $\mathrm{p}<0,05$, dengan sumbangan efektif yang lebih besar jika dibandingkan dengan analisis regresi linier sederhana. Nilai sumbangan efektif tersebut sebesar 6,9\%.

Uji hipotesis minor pertama yang dilakukan yaitu menguji apakah kecerdasan emosi dapat menjadi prediktor atas perilaku kerja kontraproduktif, uji hipotesis dalam penelitian ini menggunakan analisis regresi linier sederhana dengan bantuan IBM SPSS Statistic 20.0. Hasil uji hipotesis menunjukkan bahwa kecerdasan emosi memiliki peran terhadap perilaku kerja kontraproduktif, hal ini ditunjukkan oleh nilai signifikansi $p<0,05$. Pernyataan tersebut berarti bahwa karyawan yang memiliki kecerdasan emosi tinggi di dalam dirinya akan cenderung tidak melakukan perilaku kerja kontraproduktif dalam bekerja.

Uji hipotesis minor kedua yang dilakukan adalah menguji peran iklim organisasi terhadap perilaku kerja kontraproduktif dengan menggunakan analisis regresi linier sederhana. Hasil uji regresi menunjukkan nilai signifikansi $\mathrm{p}<0,05$, hal ini menunjukkan bahwasanya iklim organisasi memiliki peran negatif terhadap perilaku kerja kontraproduktif. Artinya, ketika karyawan berada dalam iklim organsiasi yang baik maka perilaku kerja kontraproduktif yang terjadi di dalam organisasi tersebut akan semakin rendah.

\section{Diskusi}

Penelitian terkait dengan perilaku individu dalam suatu organisasi menjadi aspek penting untuk melihat performa organisasi secara menyeluruh, di mana sebagai praktisi bidang Industri perlu memahami aspek-aspek yang selama ini 
Tabel 3.

Uji Peran Kecerdasan Emosi terhadap Perilaku Kerja Kontraproduktif

\begin{tabular}{cccccc}
\hline Variabel Independen & $\begin{array}{c}\text { Variabel } \\
\text { Dependen }\end{array}$ & $\boldsymbol{B}$ & $S E$ & $\boldsymbol{p}$ & Keterangan \\
\hline Kecerdasan Emosi & $\begin{array}{c}\text { Perilaku Kerja } \\
\text { Kontraproduktif }\end{array}$ & $-0,68$ & 0,33 & $\mathrm{p}<0,05$ & Signifikan \\
\hline
\end{tabular}

Tabel 4.

Hasil Peran Iklim Organisasi terhadap Perilaku Kerja Kontraproduktif

\begin{tabular}{cccccc}
\hline Variabel Independen & Variabel Dependen & $\boldsymbol{B}$ & $\boldsymbol{S E}$ & $\boldsymbol{p}$ & Keterangan \\
\hline Iklim Organisasi & $\begin{array}{c}\text { Perilaku Kerja } \\
\text { Kontraproduktif }\end{array}$ & $-0,87$ & 0,29 & $\mathrm{p}<0,05$ & Signifikan \\
& & & &
\end{tabular}

tidak banyak diteliti (Staw, 1991). Secara umum, dalam penelitian ini melihat lebih jauh perilaku individu yang bersebrangan dengan perilaku positif dalam organisasi. Perilaku individu dalam organisasi dapat menentukan efektivitas dari organisasi itu sendiri, yaitu perilaku kerja kontraproduktif (Dalal, 2005; Spector \& Fox, 2005). Hasil penelitian menunjukkan bahwa hipotesis dalam penelitian ini didukung, di mana hal ini berarti kecerdasan emosi dan iklim organisasi berhubungan negatif dengan perilaku kerja kontraproduktif karyawan Dinas PU Kalimantan Timur.

Perilaku kerja kontraproduktif merupakan salah satu bentuk perilaku negatif yang kerapkali terjadi di dalam organisasi dan didefinisikan sebagai perilaku tidak produktif yang berdampak pada tidak tercapainya tujuan organisasi tersebut (Rotundo \& Sackett, 2002). Penelitian yang dilakukan menunjukkan bahwa kecerdasan emosi dan iklim organisasi secara bersama-sama dapat menjadi prediktor atas perilaku kerja kontraproduktif. Hal ini dapat dilihat dari nilai $\mathrm{R}$ square sebesar $6,9 \%$, di mana dapat diartikan bahwa kecerdasan emosi yang tinggi dan iklim organisasi yang baik akan membuat perilaku negatif di tempat kerja semakin rendah. Bentuk perilaku negatif tersebut, salah satunya adalah perilaku kerja kontraproduktif. Perilaku kerja kontraproduktif diartikan sebagai perilaku yang dapat merugikan anggota organisasi dan organisasi itu sendiri (Anderson \& Pearson, 1999).

Hasil penelitian menunjukkan bahwa perilaku kerja kontraproduktif yang terjadi di sektor publik termasuk dalam kategori sedang sampai sangat tinggi sebesar 58,9\%. Data ini berarti bahwa lebih dari setengah karyawan yang bekerja di sektor publik masih melakukan perilaku kerja kontraproduktif, sesuai dengan penelitian Aquino, Galperin, dan Bennett (2004). Bentuk perilaku kerja kontraproduktif yang paling sering dilakukan oleh karyawan Dinas PU Kalimantan Timur adalah mengeluhkan hal-hal yang tidak berkaitan dengan pekerjaannya ketika berada di kantor. Perilaku ini dapat menjadi salah satu bentuk sikap yang menurunkan produktivitas karyawan. Sejalan dengan hasil penelitian Bashir et al., (2012) bahwa perilaku menyimpang di tempat kerja dapat memengaruhi kinerja individu yang bermuara pada menurunnya produktivitas.

Hasil penelitian ini membuktikan bahwa peran kecerdasan emosi memiliki pengaruh negatif terhadap perilaku kerja kontraproduktif $(B=-0,68, \quad \mathrm{p}<0,05)$. Wall (2007) menyatakan bahwa tidak mungkin 
seorang karyawan dapat meninggalkan perasaan negatif yang terjadi di rumah ketika sedang bekerja, sehingga peran kecerdasan emosi sangat penting untuk dapat mengontrol emosi tersebut dan mengungkapkan secara tepat pada kondisi tertentu. Kecerdasan emosi mengacu pada keberagaman kompetensi seorang karyawan yang berpengaruh pada kesuksesannya dalam bekerja. Hal ini dikarenakan karyawan dengan kecerdasan emosi yang baik akan cenderung menghindari perilaku kerja kontraproduktif (Emami, 2014; Jung \& Yoon, 2012; Ying \& Ting, 2013; Yin, 2010).

Kecerdasan emosi merupakan kemampuan untuk memahami dan mengetahui perasaan, serta kemampuan untuk meregulasi emosi yang dirasakan. Kemampuan ini selanjutnya dapat menjadi sebuah alat untuk mengontrol perilaku yang akan muncul di dalam lingkungan kerja. Sejalan dengan peryataan Dulewicz dan Higgs (1998) percaya bahwa kecerdasan emosi merupakan proses dalam diri seseorang untuk mengelola emosinya dan merupakan penyebab seseorang dapat bersikap sesuai etika yang berlaku. Hal ini selanjutnya berkaitan dengan kemampuan untuk merespon emosi, sosial, dan lingkungan sekitar, sehingga mampu bersikap dengan tepat dalam berbagai situasi, bahkan situasi menekan. Kemampuan dalam mengontrol diri dengan baik yang dimiliki karyawan memiliki performa yang baik ketika bekerja. Goleman (1995) menambahkan bahwasanya kecerdasan emosi adalah faktor yang dapat menjadi indikator bagi karyawan dalam menyelesaikan pekerjaan dengan baik dan kemampuan untuk mengelola pekerjaan yang diberikan.

Di samping faktor internal berupa kecerdasan emosi, iklim organisasi merupakan salah satu faktor yang ditemukan dalam literatur sebagai hal penting yang dapat meningkatkan efektivitas dan efisiensi organisasi pada saat ini (Ceyda \& Sevinc, 2012). Iklim organisasi saat ini menjadi salah satu pemicu perilaku dari anggota organisasi, sehingga menentukan bagaimana mereka bersikap. Hal ini tentu menjadi acuan bagi organiasi untuk membangun iklim organiasi, sehingga mampu meningkatkan perilaku positif dari karyawannya. Dengan demikian, organisasi dapat menciptakan lingkungan kerja yang produktif dan berkelanjutan (Al-Nasser \& Behery, 2015). Sejalan dengan pernyataan tersebut, terbukti dalam penelitian ini bahwa iklim organisasi terbukti berperan negatif terhadap perilaku kerja kontraproduktif $(B=-0,87, \mathrm{p}<0,05)$.

Mendukung pernyataan sebelumya, hasil penelitian yang dilakukan oleh Bamel, Rangnekar, Stokes, \& Rastogi (2013) menunjukkan bahwa hal-hal yang termasuk di dalam iklim organisasi merupakan aspek yang berperan penting dalam meningkatkan efektivitas manajerial suatu organisasi. Perbedaan temuan pada hasil penelitian nampak pada tidak terbuktinya bahwa terdapat perbedaan bentuk perilaku kerja kontraproduktif antara laki-laki dan perempuan. Gonzalezmulé, DeGeest, Kiersch, dan Mount (2013); Cohen, Panter, \& Turan (2013) menemukan bahwa terdapat perbedaan antara bentuk perilaku kerja laki-laki dan perempuan, sementara dalam penelitian ini tidak demikian. Hal ini juga terlihat pada tingkat pendidikan, di mana tidak terdapat perbedaan bentuk perilaku kerja kontraproduktif yang terjadi baik pada laki-laki maupun pada perempuan. Data ini berarti bahwa pada organisasi tempat penelitian berlangsung karyawan laki-laki dan perempuan pada berbagai tingkat pendidikan melakukan perilaku kerja kontraproduktif yang serupa. 
Hasil analisis regresi sederhana dilakukan sebagai analisis tambahan dalam penelitian dengan menguji masingmasing aspek kecerdasan emosi dalam perilaku kerja kontraproduktif. Data keluaran analisis SPSS menunjukkan hasil bahwa terdapat dua dari empat aspek kecerdasan emosi yang tidak berperan dalam menurunkan perilaku kerja kontraproduktif. Aspek yang berkaitan dengan bagaimana seseorang mengenali emosi dan mengatur emosi yang ada di dalam diri merupakan aspek yang memberikan sumbangan terhadap perilaku kerja kontraproduktif. Mengacu pada hasil penelitian, dapat dijelaskan bahwasanya karyawan yang dapat mengungkapkan emosi dengan tepat dan mengontrol dirinya merupakan karyawan yang cenderung menghidari perilaku negatif di tempat kerja. Data yang menunjukkan hanya dua aspek yang berpengaruh ternyata mendukung hasil analisis regresi keseluruhan bahwa kecerdasan emosi memberikan sumbangan yang lebih kecil jika dibandingkan dengan iklim organisasi.

Terdapat beberapa keterbatasan dalam penelitian ini yang perlu diperhatikan untuk penelitian selanjutnya, sebagai berikut: (1) Pengukuran perilaku kerja kontraproduktif hanya berdasar pada skala sikap yang diberikan oleh peneliti, sehingga masih terdapat subjektifitas subjek dalam mengisi kuisioner, terlebih ketika mengungkap hal negatif. (2) Pengambilan data dengan menggunakan metode kuantitatif, sehingga peneliti tidak dapat mengetahui bentuk bentuk apresiasi yang diinginkan karyawan dalam variabel iklim organisasi.

\section{Kesimpulan}

Berdasarkan hasil penelitian dan pembahasan yang telah dilakukan, dapat disimpulkan bahwa perilaku kerja kontraproduktif masih cukup banyak terjadi di kalangan PNS. Hal ini dapat diminimalisasi dengan meningkatkan kecerdasan emosi dan iklim organisasi. Sejalan dengan hasil penelitian yang menemukan bahwa kecerdasan emosi dan iklim organisasi secara bersama-sama dapat lebih efektif dalam menurunkan perilaku kerja kontraproduktif. Hal ini dapat dijabarkan menjadi: (1) Kecerdasan emosi dapat berperan untuk menurunkan perilaku kerja kontraproduktif. (2) Iklim organisasi dapat berperan untuk menurunkan perilaku kerja kontraproduktif.

\section{Saran}

Bagi organisasi, saran yang dapat diberikan adalah untuk menggunakan hasil penelitian ini sebagai acuan dalam mengurangi berbagai perilaku kerja kontraproduktif yang dapat terjadi di lingkungan kerja. Hal ini dapat dilakukan dengan memberikan pemahaman terkait dengan pentingnya kesadaran pada karyawan dalam mengenali emosi yang dirasakan. Selanjutnya karyawan akan mampu mengontrol dirinya dengan mengungkapkan emosi tersebut secara tepat sesuai dengan kondisi yang ada. Di sisi lain akan lebih efektif ketika organisasi juga mampu untuk memfasilitasi dalam menciptakan iklim kerja yang baik. Salah satu program yang dapat dilakukan adalah dengan memberikan cukup apresiasi kepada kinerja karyawan. Dengan demikian, karyawan akan merasa diapresiasi dan bekerja dengan lebih produktif. Pada penelitian ini disertakan pula rangkaian saran intervensi yang mengacu pada hasil penelitian.

Saran bagi peneliti lain, salah satunya adalah untuk membedakan demografi karyawan berdasarkan lama kerja untuk melihat perbedaan bentuk 
perilaku kerja kontraproduktif yang terjadi. Peneliti selanjutnya sebaiknya melakukan studi pendahuluan mengenai kelompok kerja atau divisi tertentu di dalam organisasi yang memiliki tingkat perilaku kerja kontraproduktif tinggi. Hal ini bertujuan untuk memfokuskan penelitian dilakukan terhadap kelompok tertentu yang lebih spesifik. Selanjutnya pemilihan lokasi atau subjek penelitian dapat dilakukan dalam sektor yang berbeda, seperti sektor privat atau karyawan yang bekerja di lapangan, sehingga akan menghasilkan data yang lebih variatif.

\section{Kepustakaan}

Ahmad, Z., \& Norhashim, M. (2008). The control environment, employee fraud and counterproductive workplace behavior: An empirical analysis. Communication of the IBIMA, 3, 145-155.

Al-Nasser, A., \& Behery, M. (2015). Examining the relationship between organizational coaching and workplace counterproductive behaviours in the United Arab Emirates. International Journal of Organizational Analysis, 23(3), 378-403. doi: 10.1108/ IJOA-08-2014-0793.

Ananta, A., Soekarni, M., \& Arifin, S. (2011). The Indonesian economy: Entering a new era. Singapore: ISEAS Publishing.

Anderson, L. M., \& Pearson, C. M. (1999). Tit-for-tat? The spiraling effect of incivility in the workplace. Academy of Management Review, 24(3), 452-471. doi: 10.5465/amr.1999.2202131

Aquino, K., Galperin, B. L., \& Bennett, R. J. (2004). Social status and aggressiveness as moderators of the relationship between interactional justice and workplace deviance.
Journal of Applied Social Psychology, 34(5), 1001-1029. doi: 10.1111/j.15591816.2004.tb02581.x

Bamel, U. K., Rangnekar, S., Stokes, P., \& Rastogi, R. (2013). Organizational climate and managerial effectiveness: An Indian perspective. International Journal of Organizational Analysis, 21(2), 198218. doi: 10.1108/IJOA-09-2011-0514 Bashir, S., Nasir, M., Qayyum, S., \& Bashir, A. (2012). Dimensionality of counterproductive work behaviors in public sector organizations of Pakistan. Public Organization Review, 12(4), 357-366. doi: 10.1007/s11115$\underline{012-0177-8}$

Beaton, D. E., Bombardier, C., Guillemin, F., \& Ferraz, M. B. (2000). Guidelines for the process of cross-cultural adaptation of self-report measures. Spine, 25(24), 3186-3191. doi: $10.1097 /$ 00007632-200012150-00014

Bowling, N. A., \& Eschleman, K. J. (2010). Employee personality as a moderator of the relationships between work stressors and counterproductive work behavior. Journal of Occupational Health Psychology, 15(1), 91-103. doi: $\underline{10.10}$ 37/a0017326.

Ceyda, G., \& Sevinc, P. (2012). Determination of high schools organizational climate procedia. Social and Behavioral Sciences, 46, 2947-2950. doi: $201 \quad 2.05 .595$ 10.1016/j.sbspro. 2012.05 .595$.

Chernyak-Hai, L., \& Tziner, A. (2013). Relationship between counter productive work behavior, perceived justice and climate, occupational status, and leader-member exchange. Journal of Work and Organizational Psychology 30(1), 1-12. doi: 10.5093 tr2014a1. 
Cohen, T. R., Panter, A. T., \& Turan, N. (2013). Prediciting counter productive work behavior from guilt proneness. Journal of Business Ethics, 114(1), 45-53. doi: 10.1007/s10551012-1326-2

Creswell, J. W. (2012). Educational research: Planning, counducting, and evaluating quantitative and qualitative research. Boston: Pearson Education, Inc.

Dalal, R. (2005). A meta-analysis of the relationship between organizational citizenship behavior and counter productive work behavior. Journal of Applied Psychology, 90(6), 1241-1255. doi: 10.1037/0021-9010.90.6. 1241.

Davies, M., Stankov, L., \& Roberts, R. D. (1998). Emotional intelligence: In search of an elusive construct. Journal of Personality and Social Psychology, 75(4), 989-1015. doi: 10.1037/0022-3514.75.4.989

Deshpande, S. P, Joseph, J., \& Shu, X. (2005). The impact of emotional intelligence on counterproductive behaviour in China. Management Research News, 28(5), 75-85. doi: 10. $\underline{1108 / 01409170510629050}$

Dulewicz, V., \& Higgs, M. (1998). Emotional intelligence: Can it be measures reliably and validly using competency data? Competency, 6(1), 1-5.

Ellias, S. M. (2013). Deviant and criminal behavior in the workplace. New York: New York University Press.

Emami, S. M. (2014). The effects of emotional intelligence on counterproductive work behaviors. Management Science Letters, 4(8), 1797-1800. doi: 10.5267/ j.msl. 2014. $\underline{7.003}$

Fox, S., Spector, P. E., \& Miles, D. (2001). Counterproductive work behavior (CWB) in response to job stressors and organizational justice: Some mediator and moderator tests for autonomy and emotions. Journal of Vocational Behavior, 59(3), 291-309. doi: $\underline{10.1006 / j v b e .2001 .1803}$

Goleman, D. (1995). Emotional intelligence. New York: Bantam Books.

Gonzalez-mulé, E., DeGeest, D. S., Kiersch, C. E., \& Mount, M. K. (2013). Gender differences in personality predictors of counterproductive behavior. Journal of Managerial Psychology, 28(4), 333-353. doi: 10.1108/JMP-122012-0397

Ghozali, I. (2013). Aplikasi analisis multivariate dengan program SPSS. Edisi Ketujuh. Semarang: Badan Penerbit Universitas Diponegoro.

International Labour Organization. (2016). ILOSTAT-ILO database of labour statistics. Retrieved from http://www .ilo.org/global/statistics-and-databas es/lang--en/index.htm

Jung, H. S., \& Yoon, H. H. (2012). The effects of emotional intelligence on counterproductive work behaviors and organizational citizen behaviors among food and beverage employees in a deluxe hotel. International Journal of Hospitality Management, 31(2), 369-378. doi: 1016/j.ijhm.2011.06.008.

Klotz, A. C., \& Buckley, M. R. (2013). A historical perspective of counter productive work behavior targeting the organization. Journal of Management History, 19(1), 114-132. doi: $10.1108 / 17511341311286222$

Petrides, Norah Frederickson, Adrian Furnham (2004). The role of trait emotional intelligence in academic performance and deviant behavior at school. Personality and individual differences journal. 36, 277-279. doi: $\underline{10.1016 / 50191-8869(03) 00084-9}$

Mayer, J. D., \& Salovey, P. (1997). Emotional development and emotional 
intelligence: Educational implications. New York: Basic Books.

Martinko, Michael J. Gundlach, Scott C. Douglas. (2003). Toward an integrative theory of counterproductive workplace behavior: A causal reasoning perspective. International Journal of Selection and Assesment, 10(1), 36-50. doi: 10.1111/1468-2389.00192

Mazolla, J. J., \& Kessler, S. R. (2012). Counterproductive work behaviors and their ethical dilemmas: Creating just, respectful, and productive organizations. International Handbooks of Quality-of-Life, 5, 157-179. doi: 10.1007/978-94-007-4059-4

Kanten, P., Funda El Ülker (2013). The Effect of organizational climate on counterproductive behavior: An empirical study on the employees of manufacturing enterprise. The Macrotheme Review Journal, 2(4), 144160

Peña-Suárez, E., Muñiz, J., CampilloÁlvarez, A., Fonseca-Pedrero, E., \& García-Cueto, E. (2013). Assessing organizational climate: Psychometric properties of the CLIOR scale. Psicothema, 25(1), 137-44. doi: 10.7334/psicothema2012.260

Penney, L. M., \& Spector, P. E. (2005). Job stress, incivility, and counter productive work behavior (CWB): The moderating role of negative affectivity. Journal of Organizational Behavior, 26(7), 777-796. doi: 10.1002/job.336

Pricewaterhouse Coopers. (2016). Global Economic crime survey. http://www. pwc.com/gx/en/economic-crime-survey/pdf/GlobalEconomicCrimeSurve y2016.pdf. Diakses tanggal 21 April 2016 pukul 08.12 WIB.

Prokal.co. (2016). BKD Kaltim pecat 45 PNS. Diambil dari http://samarinda.prokal .co/read/news/4426-bkd-kaltimpecat-45-pns.html.

Republik Indonesia. (2003). Undangundang Republik Indonesia tahun 2003 tentang ketenagakerjaan. Diambil dari http://hukum.unsrat.ac.id/uu/uu 13 03.htm.

Rotundo, M., \& Sacket, P. R. (2002). The relative importance of task, citizenship, and counterproductive performance to global ratings of job performance: A policy capturing approach. Journal of Applied Psychology, 87(1), 66-80. doi: $\underline{10.1037}$ 0021-9010.87.1.66.

Sonnentag, S., \& Frese, M. (2002). Phsychological management of individual performance. Chichester: Johm Wiley \& Sons, Ltd.

Spector, P. E., Bauer, J. A, \& Fox, S. (2010). Measurement artifacts in the assessment of counterproductive work behavior and organizational citizenship behavior: Do we know what we think we know?. The Journal of Applied Psychology, 95(4), 781-790. doi: $\underline{10.1037 / a 0019477}$

Spector, P. E., \& Fox, S. (2002). An emotion-centered model of voluntary work behavior: Some parallels between counterproductive work behavior and organizational citizenship behavior. Human Resource Manage-Ment Review, 12(2), 269-292. doi: 10.1016/S1053-4822(02)00049-9

Spector, P. E., \& Fox, S. (2005). The stressor-emotion model of counterproductive work behavior. Diedit oleh S. Fox \& P. E. Spector. Counterproductive work behavior: Investigations of actors and targets: 151174. Washington, DC: American Psychological Association.

Staw, B. M. (1991). Psychological dimensions of organizational behavior. New Delhi: Maxwell Macmillan. 
Van Rooy, D. L., \& Viswesvaran, C. (2004). Emotional intelligence: A metaanalytic investigation of predictive validity and nomological net. Journal of Vocational Behavior, 65(1), 71-95. doi: $\underline{10.1016 / \mathrm{s} 0001-8791(03) 00076-9}$.

Wall, B. (2007). Coaching for emotional intelligence: The secret to developing the star potential in your employess. New York: AMACOM.
Ying, C. Y., \& Ting, S. K. T. (2013). The effects of emotional intelligence on counterproductive work behaviors and organizational citizenship behaviors. International Journal of Accounting and Business Management (IJABM), 1(1), 168-179. http://www.ft ms.edu.my/journals/images/Docume nt/IJABM/April\%202013/The\%20Effe cts $\% 200 f \% 20$ Emotional $\% 20$ Intellige nce $\% 200$ n.pdf.

Yin, L. C. (2010). Emotional intelligence as a moderator in the relationship between negative emotion and counterproductive work behaviors. Hong Kong: Hong Kong Baptist University. 